\title{
Sargent and the Wyeths in London
}

Sargent and the Sea, Royal Academy of Arts (10 July - 26 September 2010)The Wyeth Family: Three Generations of American Art, Dulwich Picture Gallery (9 June - 22 August 2010)

Jennifer A. Donnelly

\section{(2) OpenEdition}

\section{Journals}

Electronic version

URL: https://journals.openedition.org/transatlantica/4958

DOI: 10.4000/transatlantica.4958

ISSN: 1765-2766

\section{Publisher}

Association française d'Etudes Américaines (AFEA)

\section{Electronic reference}

Jennifer A. Donnelly, "Sargent and the Wyeths in London", Transatlantica [Online], 1 | 2010, Online since 01 October 2010, connection on 10 February 2023. URL: http://journals.openedition.org/ transatlantica/4958 ; DOI: https://doi.org/10.4000/transatlantica.4958

This text was automatically generated on 10 February 2023.

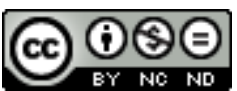

Creative Commons - Attribution-NonCommercial-NoDerivatives 4.0 International - CC BY-NC-ND 4.0 https://creativecommons.org/licenses/by-nc-nd/4.0/ 


\section{Sargent and the Wyeths in London}

Sargent and the Sea, Royal Academy of Arts (10 July - 26 September 2010)The Wyeth Family: Three Generations of American Art, Dulwich Picture Gallery (9 June - 22 August 2010)

Jennifer A. Donnelly

1 Paintings by some of America's foremost representational painters decked the walls of two of London's oldest arts institutions in summer 2010: the Royal Academy of Arts featured early marine scenes by John Singer Sargent, while across town the Dulwich Picture Gallery showcased work by various members of the Wyeth clan.

2 Comparisons between Sargent and the Wyeths are much less evident than contrasts. Sargent epitomizes the cosmopolitan, transatlantic artist, whereas the Wyeths, particularly Andrew, verged on isolationists, repeatedly portraying the same East Coast landscapes and locals. Sargent's childhood was spent migrating between Italy (where he was born), France, Germany, and Switzerland, gaining an education in galleries and churches. He had studios in Paris, then London, but traveled incessantly, drawing and painting everywhere he went. His canvases evoke lush old World settings, exotic or aristocratic beauties and men of position and wealth; he did not visit the United States until he was twenty years old. The Wyeths, on the other hand, have been based in Chester County, Pennsylvania, since 1902, and have summered in Maine since the 1930s. These locations and their longtime inhabitants serve as subjects for much of the family's work, remembered perhaps most commonly for Andrew's stark compositions in shades of brown, beige, and grey. Andrew first visited Europe at the age of $60^{1}$ and his painter sister Carolyn lived in the family house until her dying day.

3 Still, the juxtaposition of the two shows makes apparent certain parallels amongst these representational artists, particularly regarding the negative reception of their work amongst critics - a persistent habit that ultimately suggests more about the critics' preoccupations than about the art itself. 


\section{The Siren Call of the Sea}

4 While water holds a different meaning for an expatriate than for one rooted in a particular region in the motherland, both exhibitions contain a strong dose of marine imagery. This is of course the focus of the show on Sargent, who sketched ships and ocean scenes from an early age. The Wyeth Family opens with paintings by patriarch Newell Convers (N.C.) of historical merchant ships made on commission for the First National Bank of Boston in 1923 (Phoenician Biremes, Elizabethan Galleons, etc), and views of coastal Maine from the all three generations of the family are interspersed throughout the galleries. Advertising for the Dulwich exhibition use N.C. Wyeth's A Maine Fisherman (1933), a portrait of a strong-jawed, broad-chested seaman at the helm of a boat, the water and banks behind him depicted in bold strokes and color. The Royal Academy publicity takes Sargent's Atlantic Storm (1876, Curtis Galleries, Minneapolis), which depicts the swelling waves seen from the pitching deck of an ocean steamer.

While publicists may have hoped to lure visitors trapped in the city during the warm months with seaside images, the role of the sea in Sargent's work does hold some significance in his oeuvre. His own family history is dominated by seafaring men: the family founder was a merchant and ship owner, and his grandson established a far-east trading company that prospered until the time of Sargent's grandfather. Sargent's father, who would have otherwise inherited the business, apparently harbored hopes that his son's love of sketching boats would translate into a career at sea - a vision would not be realized, to the relief of the painter's future admirers (and the chagrin of his detractors) ${ }^{2}$.The Royal Academy exhibition is the first dedicated entirely to the painter's marine work ${ }^{3}$.

6 Sargent's pieces at the Royal Academy were made between 1874 and 1880, early in his career, when he was aged between 18 and 24. During this period he was receiving formal training in Paris at the studio of Carolus-Duran and at the Académie des BeauxArts. The works were made during summer breaks to Normandy, Brittany, Italy, and Morocco. In addition to oils that were exhibited during his lifetime, several studies and preparatory drawings are on display, as well as a scrapbook from these years containing sketches, watecolors, ephemera, and notes (Metropolitan Museum of Art). The various pieces depict seaside landscapes as well as people eking out their living from the sea. En route pour la pêche (Setting out to Fish)(1878, Corcoran Gallery of Art, Washington, DC), forms a centerpiece, along with a second version of the work, Fishing for Oysters at Cancale (1878, Museum of Fine Arts, Boston. One of Sargent's first exhibition pieces, it was displayed at the Paris Salon in 1878 to positive acclaim. The scene depicts a group of Breton women wading languorously across the sand towards the water to gather their harvest, conversing as they go, baskets under their arms. Light sparkles on the puddles in the sand and the workmanship conveys spontaneity, although the many sketches and studies, also on display, reveal the painter's meticulous methods of preparation.

7 One of the show's strengths, in fact, is the inclusion of Sargent's drawings. These make evident the astonishing immediacy of his skill, which the rich colors, deft brushwork, and complex compositions of his oils tend to belie. Whatever one's opinion of the finished works, the artist was undisputedly a remarkably capable draftsman ${ }^{4}$. The works clearly display the technical virtuosity that Sargent had achieved at a young age, 
reminding us of Henry James's description of "the slightly 'uncanny' spectacle of a talent which on the very threshold of its career has nothing more to learn." 5

In Atlantic Stormand Mid-Ocean, Mid-Winter (1876, private collections), Sargent paints the crests of the waves with precision, giving remarkable solidity to the liquid, amorphous masses of water. In Atlantic Storm the proportion of the human figures huddled on the ship deck to the massive wave rising above their heads invoke terror and wonder before the immensity of the sea. The inspiration for the pictures came during Sargent's return from the United States on his very first visit to his country of nationality; there lurks a hint of a darker side to the glamour of the transatlantic passage. Here we glimpse a brooding twenty-one year old Sargent, emerging from adolescence onto the threshold of adulthood.

While Sargent's father might have preferred the navy to art school for his son, painting was for the Wyeths very much a family affair. N.C. instructed his children Andrew, Carolyn and Henriette in drawing and painting, as well as the husbands of his daughter Henriette (Peter Hurd) and his daughter Ann (John McCoy). Carolyn in turn taught Andrew's son Jamie. The Dulwich show focuses on N.C., Andrew, and Jamie, with a nod to Henriette and her husband. A large portion of the roughly seventy works are by N.C. His illustrations for books such as Rip Van Winkleby Washington Irving and The White Companyby Sir Arthur Conan Doyle (1922) can be seen in copies of the published volumes in display cases. On the walls hang the large-scale oils that N.C. produced for such projects, which were reduced and reproduced mechanically for publication. The large format gives a closer view of the meticulous attention given to details in costumes and background, the illustrator's penchant for historical accuracy, and the compositional tricks used to convey action.

N.C.'s famous son Andrew took these lessons of detail and precision but translated them into a style his own. While he is represented by only around a dozen pieces, these cover a wide chronological swath, from the 1930s to the early $21^{\text {st }}$ century. A few are in egg tempera, a laborious Renaissance technique that the painter learned from his brother-in-law Peter Hurd. Andrew's much more quickly executed watercolors are equally extraordinary, and those on display give a glimpse of the seemingly empty landscapes, evocative textures, and enigmatic composition emblematic of his work. In The Forge (1984), two old stone buildings with unadorned white walls and black roofs stand amongst a few bare black trees and a snowy field. The unadorned rectangles for walls and triangles for roofs appear simple, and the palette of black and white - much of which is the unpainted paper - restricted. On closer examinations, details such as the worn façade of the stucco, weathered unevenly after an untold number of seasons, give an overall effect of startling immediacy and precision, particularly for the fluid nature of the watercolor.

11 Andrew's son Jamie constitutes the third generation of Wyeth artists. His subjects are more eclectic than those of his forebears, and the effects slightly less consistent. The familiar landscapes of Pennsylvania and Maine reappear in works such as Pumpkinhead visits the Lighthouse (2000), which evokes some of the mystery of his father's work, without as much technical precision. Jamie developed a fascination for the dancer Rudolf Nureyev in the late 1970s and the exhibition includes a portrait study, which is technically proficient if not particularly memorable in itself. His September 11, however, a watercolor of the celebrated scene of firefighters raising the American flag at the site of the 2001 World Trade Center attacks, borders on kitsch. 
12 N.C.'s daughter Henriette, who spent her adult life in New Mexico, is represented by a few still lifes and portraits, and her husband by a mountain landscape in egg tempera, a reminder of the technique that he taught to his more celebrated brother-in-law. Still, even these few pieces relate an alternate bend in the family history, one that passed closer to the representational Modernism flourishing in the American Southwest at the time.

13 The works in The Wyeth Family are loaned from the Bank of America Merrill Lynch through the company's "Art in Communities" program. The selection of works thus stems from their appurtenance to this corporate collection, rather than from any iconographical, historical, or stylistic coherence. This curatorial approach (or lack thereof) unfortunately does not do justice to the family's rich and diverse legacy. This is a shame, because while London may be a natural setting to view Sargent (who was a Royal Academician, based in the UK from 1886 until his death), the opportunity to see pieces by the Wyeths outside of the United States is rare ${ }^{6}$. The uneven quality of works is all the more unfortunate given the tendency of scholars and critics to disparage the Wyeths. London reviewer Charles Darwent quipped that "tickets to this show cost $£ 9$, which works out at £3 per interesting picture"7; the desultory, almost haphazard selection provides little ammunition for defense. The show lacks anything quite as refined as Andrew's egg temperas and drybrushes in the collections of the Brandywine River Museum in Chadds Ford and the Farnsworth Art Museum in Rockland, Maine. More could have been done to draw out how engaging readers must have found N.C.'s illustrations before the availability of video games, DVDs, high-speed internet, and hyperlinked text. Jamie comes off looking somewhat amateur; the show includes nothing to match his monumental Portrait of Pig(1970, Brandywine River Museum).

\section{Mere Illustration?}

14 Even had the shows included a more studied selection of the Wyeths' work, the truth would remain that critics love to hate them. To a certain extent, the same was true of Sargent. Outsiders despite public popularity and financial success, the Wyeths and Sargent do not easily fit academic categories of school or styles. Sargent belongs neither to Impressionism, Fauvism, or Cubism. Andrew Wyeth stood apart from his contemporaries in Abstract Expressionism and Minimalism; furthermore, he was trained by a commercial illustrator (his father). Critics thinly veil frustration, even anger, that in the 1940s and 1950s Andrew Wyeth did not paint like Jackson Pollock, take a studio in New York, nurture an intimate relationship with an international dealer, or at least fail trying to achieve these ends.

Sargent likewise was out of fashion with scholars, by the time of his death in 1925 until well into the 1950s. Painter and critic Roger Fry declared in 1926 that his work was "wonderful indeed, but most wonderful [is] that this wonderful performance should ever have been confused with that of an artist."

Upon Andrew's death in 2009, British critic Jonathan Jones disparaged "his vision of an ideal America of hunters and farmers and good country folk," describing it as "fanciful and idiotic" and likening it to the ideologies of President George W. Bush".At the occasion of the 2006 blockbuster Andrew Wyeth: Memory and Magic (Philadelphia Museum of Art \& High Museum of Art, Atlanta), New York Times critic Ken Johnson 
compared certain of the paintings to advertisements for Pottery Barn, a chain of household goods stores, and his models to "Ralph Lauren ads"10.

Lewis Mumford wrote in 1930 that Sargent "remained to the end an illustrator...the most adroit appearance of workmanship, the most dashing eye for effect, cannot conceal the essential emptiness of [his] mind." Similarly, N.C. is generally written off as an illustrator, with the implication that 'mere' should always precede the term.

Just underneath the surface of these critiques lies the presumption that representational painting is less valid than abstract expression, and that persisting in painting figuratively after the articulation of alternative forms of expression must be indicative of an outlook that is sentimental and superficial, while at the same time championing middlebrow taste, particularly if museum audiences like the work. And if attendance numbers are reliable indicators, they do.

19 While the automatic association of popularity with superficiality can be quickly dismissed on logical grounds, the pejorative attitude towards figurative work, even commercial illustration, is puzzling at a moment when scholars of visual culture embrace ephemera, murals, posters, and advertising art as socially and aesthetically significant documents of culture. Also puzzling is the English critic who invokes the 'fantasy' of Andrew Wyeth's paintings. An equivalent critique would have a New Yorker accusing a landscape painter in Yorkshire of dreaming up its rolling green hills and stately old homes. That author clearly never visited or saw a photograph of Chester County, Pennsylvania; for to this day, many fields and roads remain exactly, hauntingly, as Wyeth painted them, despite the mushrooming development and population of the area over the past two decades.

20 N.C.'s great-granddaughter Victoria Wyeth, who avowedly does not paint, now leads tours through the considerable collection of Wyeth work at the Brandywine River Museum. Her approach is distanced from abstract frameworks of art history, theory, and criticism; she simply asks viewers to look at the paintings, and shares knowledge gained firsthand about the pictures from their creators over a long time. In July 2010, days before the opening of the show in London, she shared reflections from her grandfather 'Andy' and uncle Jamie about the significance of objects and places repeated in their paintings. References are often to memories and events shared by the family; they are highly idiosyncratic reactions to the landscapes in which they passed their lives and the restricted group of neighbors, friends, and acquaintances who shared these places with them. A certain language is repeated throughout the paintings, as with family jokes and nicknames. Some of the associations are morbid, some banal, many conscientious of the senses beyond seeing that depictions of objects, places, and people can stir.

21 Each in their own way, the painters of the Wyeth family mapped out that visual language. The Wyeth legacy has not followed the high-selling trends of the international art market - although, to be sure, their work, especially that by Andrew, commands considerable sums - but the lack of adulation from the critical establishment at no point deterred their activity. They continued their course with persistence and steadfastness; without a dramatic spectrum of evolution, perhaps, but also without gimmicks.

22 Sargent's reputation was resuscitated in the 1950s, perhaps because the worlds of which his critics were wary had indisputably vanished after the World Wars. Perhaps the same will be true of the Wyeths, particularly Andrew, after more time has passed, 
and the fields and barns he painted are transformed into drive-up drugstores and residential lofts. It is loss, perhaps, that wakes the eye to the value of what was once there.

The London shows are not exactly watersheds in scholarship, although they are well displayed and visually pleasant - something like 'beach reading' for the museumgoer.

\section{BIBLIOGRAPHY}

DARWENT, Charles, “Only one winner in this generation game”, The Independent (UK), 13 June 2010.

JAMES, Henry, “John S. Sargent”, Harpers Magazine, October 1887, 683-691.

JoHnson, Kenneth, “ 'Andrew Wyeth: Memory and Magic' at the Philadelphia Museum of Art”, New York Times, April 18, 2006.

JONES, Jonathan, “On Art Blog”, The Guardian (UK), 20 January 2009.

PATON, Priscilla, Abandoned New England: Landscape in the Work of Homer, Frost, Hopper, Wyeth, and Bishop, University of New Hampshire, 2003.

PRETTEJOHN, Elizabeth, Interpreting Sargent, Stewart, Tabori \& Chang, 1998.

Sargent, Exhibition Catalogue. Ed. Elaine Kilmurray and Richard Ormond. Tate Gallery Publishing, 1998.

Sargent and the Sea, Exhibition Catalogue. Ed. Richard Ormond. Corcoran Gallery of Art, 2009.

\section{NOTES}

1. The occasion was Andrew's induction into the Académie française des beaux arts in 1977; he was the first American artist since John Singer Sargent to be admitted.

2. Richard Ormond, "Sargent and the Sea: Introduction", Sargent and the Sea, Corcoran Gallery of Art, 2009, 3-38; 7-8.

3. The catalogue published for the exhibition includes fine essays by curator Sarah Cash and eminent Sargent scholar Richard Ormond, amongst others. The show was curated by the Corcoran Gallery of Art and shown there and at the Houston Museum of Fine Arts.

4. The small show "Sketch everything and keep your curiosity fresh" at the Corcoran in 1999 was a wonderful and rare exhibition dedicated uniquely to Sargent's drawings.

5. Henry James. John S. Sargent, Harpers Magazine, October 1887, 683-691; 684.

6. Nearly the only extra-American exhibitions are An American Vision: Three Generations of Wyeth Art, which made stops in several European capitals in 1987-1988, and Andrew's one-man show at the Royal Academy in 1980 as well as several in Japan since the 1980s.

7. Charles Darwent, "Only one winner in this generation game", The Independent (UK), 13 June 2010.

8. Elizabeth Prettejohn. Interpreting Sargent, Stewart, Tabori \& Chang, 1998, 73. 
9. Jonathan Jones, On Art Blog, The Guardian, 20 January 2009: www.guardian.co.uk/ artanddesign/jonathanjonesblog/2009/jan/20/andrew-wyeth-america-george-bush

10. Kenneth Johnson, “'Andrew Wyeth: Memory and Magic' at the Philadelphia Museum of Art', New York Times, April 18, 2006.

INDEX

Subjects: Trans'Arts

AUTHOR

JENNIFER A. DONNELLY

Université Paris VII 